\title{
TEKTONICKÁ ANALÝZA OKRAJOVÉHO ZLOMU BLANENSKÉHO PROLOMU
}

\author{
Tectonic analysis of marginal fault of Blansko trough \\ Marko Skoršepa, Rostislav Melichar \\ Ústav geologických věd, Přirodovědecká fakulta Masarykovy univerzity, Kotlářská 2, 611 37 Brno, e-mail: 423646@mail.muni.cz
}

(24-14 Boskovice)

Key words: fault, thrust fault, Blansko trough, tectonics, kinematics

\begin{abstract}
Sand quarry under study is situated in the western surroundings of Dolni Lhota village north of Blansko town. The quarry uncovers interested tectonic contact of Blansko Trough and the Brno Massif, which may be damaged during some time. So, this work may be one of last possibilities to study the fault core. Blansko Trough is fulfilled by Cretaceous sedimentary rocks with almost subhorizontal bedding. The trough is limited by reverse marginal fault with granodiorite of the Brno Massif. Cretaceous sediments near the fault have overturned bedding steeply inclined to the southwest, which is caused by the bending and dragging along the fault striking in $N W-S E$ direction with inclination to the SW. In addition, there was found bedding of Cretaceous sediments steeply dipping to SSE at that point. Magnetic lineation K1 detected by analysis of anisotropy of magnetic susceptibility (AMS) in the deformed clays was subhorizontal trending in SW-NE. K2 is inclined to the east and poles of the magnetic foliation (K3) are showing that the magnetic foliation is moderately dipping mainly to SSE, which corresponds with bedding measured at that point. It can be concluded that bedding at that point and outputs of AMS were affected by some minor transversal fault, along which deformations led to the anomaly oriented structures.
\end{abstract}

Úvod

Okrajový zlom blanenského prolomu tvoří kontakt biotitického granodioritu brněnského batolitu a kř́ídových sedimentů. Zlomový kontakt těchto hornin je odkrytý v pískovně v Dolní Lhotě, s. od Blanska (N $49^{\circ}$ $22^{`} 32.624^{\prime \prime}$, E $\left.16^{\circ} 37^{\prime} 32.6831^{\prime \prime}\right)$. Křídové jílovce, pískovce a opuky jsou zde vyvlečené podél zlomu do podoby překocené vrásy s velmi strmou vrstevnatostí (Melichar - Čech 1999). Překocená pozice byla rozpoznaná podle fosilního obsahu povrchových výchozů již Zvejškou (1944). Starší podrobné geologické mapování křídových útvarů v blanenském prolomu ukázalo, že kř́ídové vrstvy jsou také mnohokrát narušené příčnými zlomy směru SSV-JJZ až SV-JZ (Kettner 1941). V bazické žíle v těsné blízkosti tektonického kontaktu se Haviŕrovi (1998) podařilo naměřit strmé mikrozlomy ve směru SV-JZ se subhorizontálním rýhováním, tj. $v$ př́ičném směru vůči okrajovému zlomu. $\mathrm{V}$ dnešní době je část lomu, kde je kontakt odkrytý, nevyužívaná a postupně se zasypává sutí a zarůstá. Proto byla lokalita podrobena výzkumu, dokud je kontakt ještě částečně př́stupný.

\section{Metodika}

Terénní práce a měření anizotropie magnetické susceptibility (AMS) probíhaly na jaře roku 2016. Metodika spočívala ve sběru kompasových dat v terénu, odkopání plochy zlomu a odebrání vzorků jílu z jádra zlomu, které byly zpracované pomocí měření AMS s cílem určit směr lineace a tedy směr pohybu na zlomu.

Mapa se seznamem dokumentačních bodů A, B a C je zobrazena na obrázku 1 . Výběr místa pro odkopání plochy zlomu spočíval v porovnání se staršími nákresy

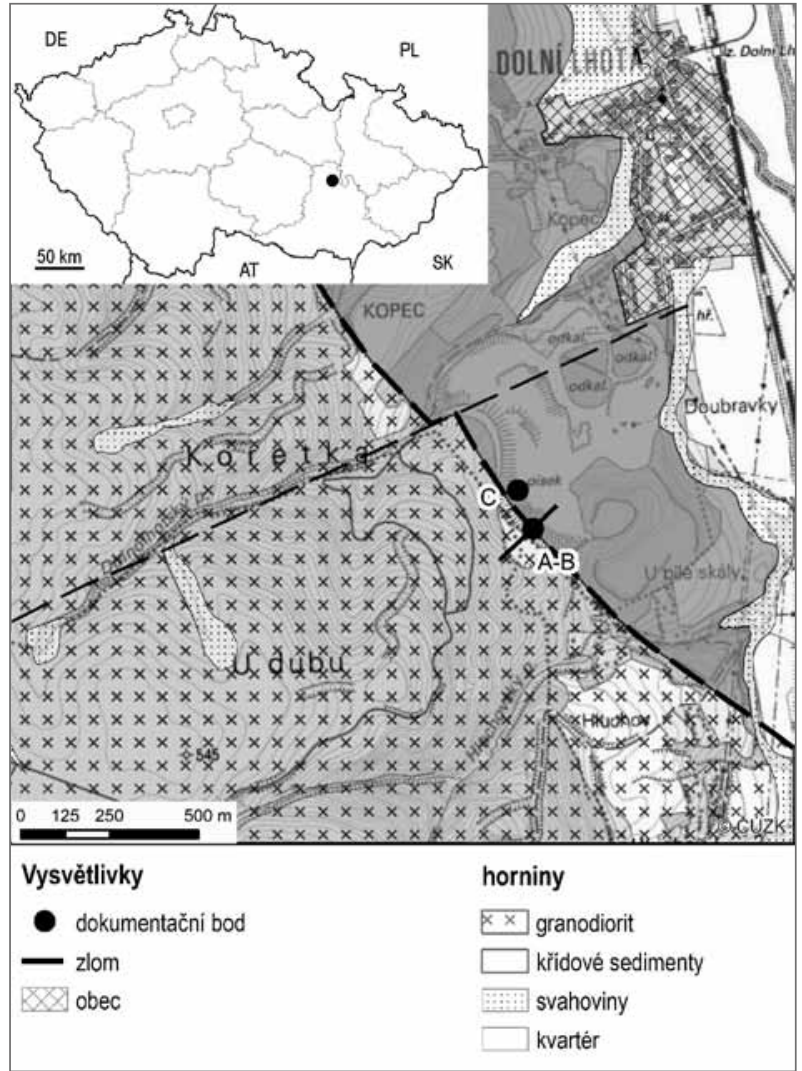

Obr. 1: Zjednodušená geologická mapa okolí studované lokality s vyznačením dokumentačních bodů $\mathrm{A}, \mathrm{B}, \mathrm{C}$.

Fig. 1: Simplified geological map of the surroundings of studied locality with position of documentation points A, B, C. 

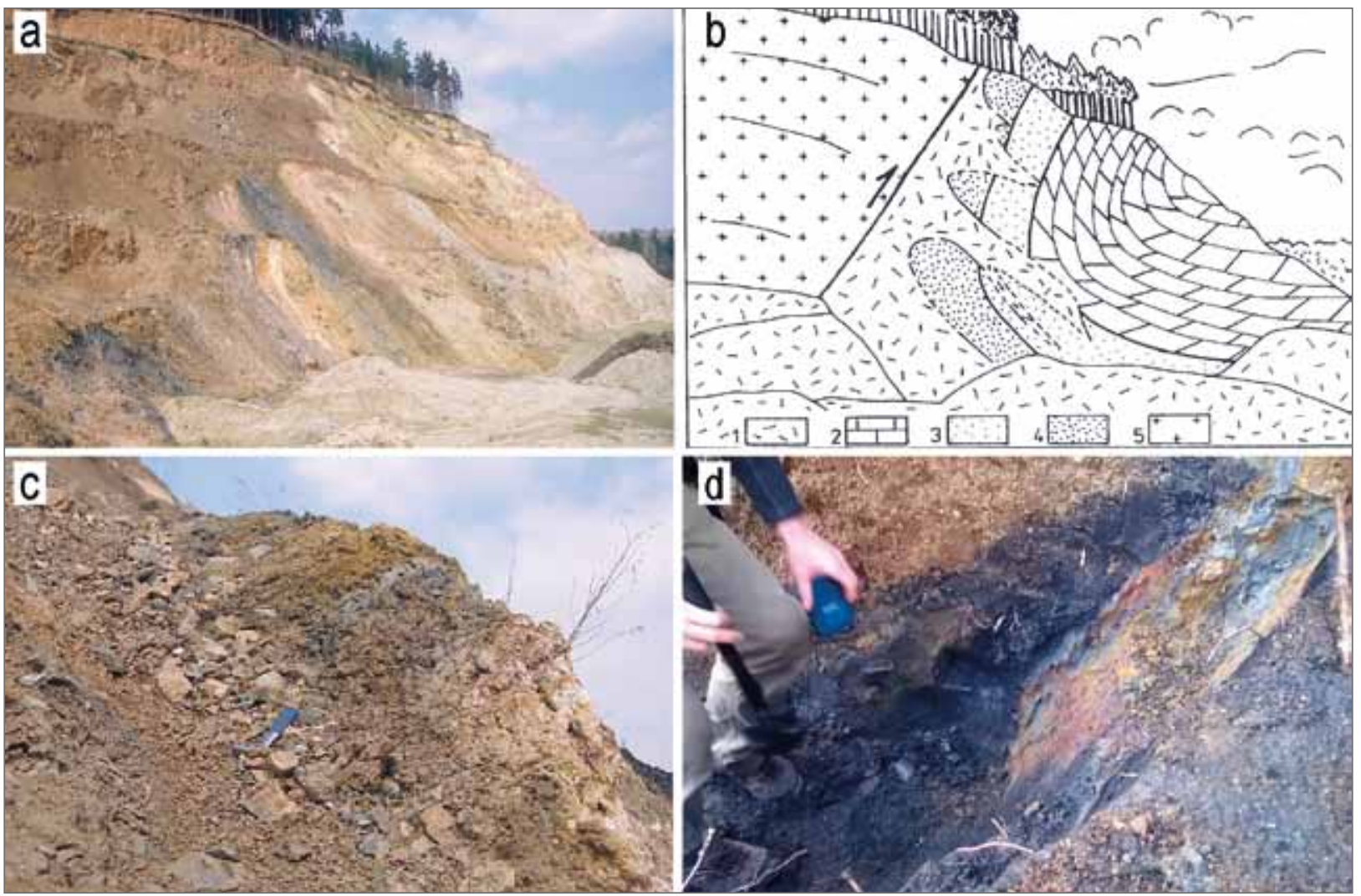

Obr. 2: Okrajový zlom na styku kř́ídových hornin blanenského prolomu a granodioritu brněnského masivu v lomu v Dolní Lhotě; a - celková situace, stav asi z r. 1998; b - geologická stavba podle fotografie a (Melichar - Čech 1999), vysvětlivky: 1. sut', 2. opuka, 3. glaukonitický pískovec, 4 . pískovec, 5. granodiorit; c - odkryv plochy okrajového zlomu se zřetelnými různobarevnými pruhy jílu ve směru pohybu, stav asi z roku 1998; d - jádro zlomu nově odkryté pro odběr vzorků, situace v r. 2016.

Fig. 2: Marginal fault at the contact of Cretaceous rocks of Blansko Trough and granodiorite of the Brno Massif in Dolní Lhota quarry; a - overview of the locality, situation app. from 1998; b - geological situation based on figure a (Melichar - Čech 1999), key: 1 debris, 2 sandy marl, 3 glauconite sandstone, 4 sandstone, 5 granodiorite; $c$ - outcrop of the marginal fault with belts of coloured clays in movement direction, situation app. from 1998; d - fault core uncovered for new sampling, situation of 2016.

lomu (obr. 2) při zohlednění okolního terénu.

Po odkopání plochy zlomu na místě A byla pomocí kompasu změřena orientace vrstevnatosti a plochy zlomu intersekční metodou. V bodě B byla po odkopání suti změřena orientace vrstevnatosti opět intersekční metodou. Ve spodní části lomu, v bodě $\mathrm{C}$, byla změřena vrstevnatost přímo pomocí kompasu.

Naměřená kompasová data vrstevnatosti křídových sedimentů, samotné plochy zlomu a plochy odběru vzorků byly zobrazeny jako póly ploch v azimutálních diagramech Lambertovy projekce na spodní polokouli pomocí programu Spheristat 3.

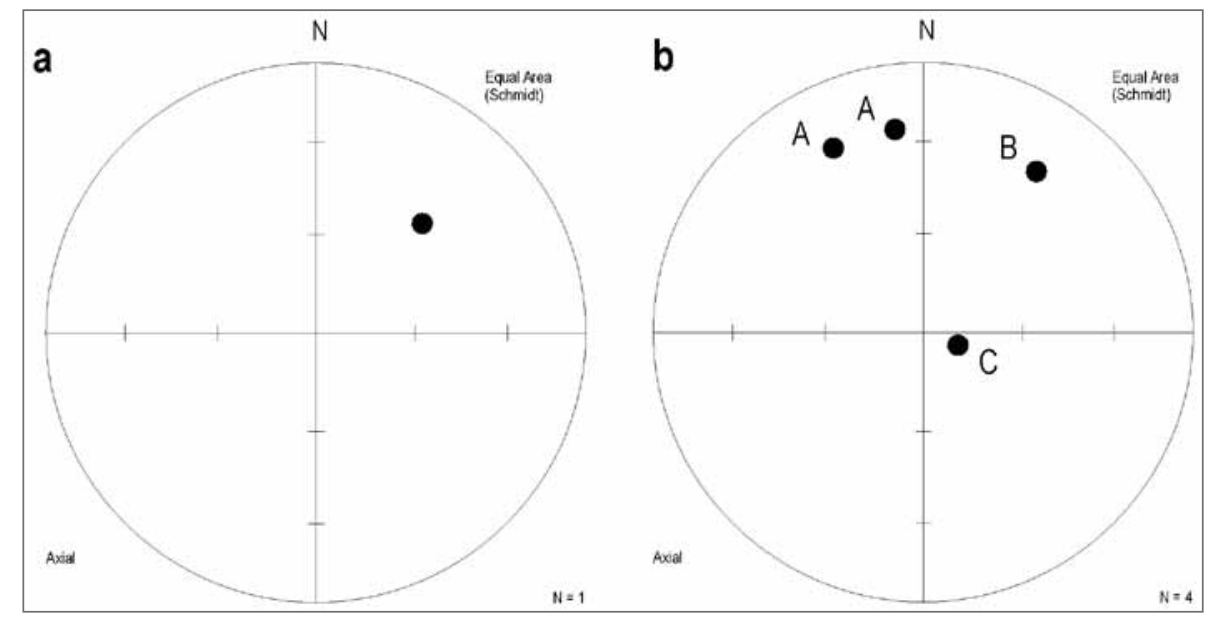

Obr. 3: a - Orientace plochy zlomu odkrytého v pískovně v Dolní Lhotě (pól plochy v azimutální Lambertově projekci na spodní polokouli); b - orientace ploch vrstevnatostí křídových sedimentů $\mathrm{v}$ pískovně v Dolní Lhotě (pól plochy v azimutální Lambertově projekci na spodní polokouli): A, B, C - vrstevnatosti z jednotlivých lokalit.

Fig. 3: a - Orientation of the fault surface outcropping in the sand quarry in Dolní Lhota village (pole of surface in azimuthal Lambert projections on the lower hemisphere); $b$ - orientation of the bedding from the Cretaceous sedimentary rocks in the sand quarry in Dolní Lhota village (poles of surface in azimuthal Lambert projections on the lower hemisphere): A, B, C-different sites of data collection. 
V bodě A bylo odebráno 10 orientovaných vzorků jílu z jádra zlomu na analýzu AMS pomocí metodiky podle Tarlinga a Hroudy (1993). Vzorky 4 až 10 byly odebírané vtláčením odběrové krabičky kolmo na plochu zlomu. Dva kontrolní vzorky byly vtláčené ve směru plochy zlomu kolmo k ploše 106/89 asi $3 \mathrm{~cm}$ nad zlomem. Kontrolní vzorek 3 byl vtlačen kolmo k ploše 38/30. Pomocí odebraných kontrolních vzorků bylo možné provést kontrolu a vyloučit tak př́padnou chybu při stanovení orientace zlomu. Orientované vzorky odebrané v terénu byly analyzované kappametrem MFK1-FA (multi functional kappabridge), což bylo bezplatně umožněno laskavostí firmy AGICO. Pro zobrazení výstupů z kappametru byl využit program Anisoft, který převádí hlavní směry elipsoidu susceptibility do Lambertovy projekce na spodní polokouli.

\section{Výsledky}

Zjištěná plocha zlomu odkrytého v bodě A (obr. 3a) se uklání pod středním úhlem jz. směrem. Plochy vrstevnatosti křídových sedimentů v bodě A se uklání strmě jjv. směrem (obr. $3 \mathrm{~b})$. V bodě B je vrstevnatost strmě ukloněná jz. směrem (obr. $3 b$ ). $V$ bodě $C$ se naměřená vrstevnatost uklání zsz. směrem a je téměř subhorizontální (obr. 3b).

Směry všech hlavních magnetických susceptibilit jsou zobrazené na obrázku 4. Magnetická lineace, kterou představuje K1, je horizontální a probíhá ve směru JZ-SV. Směr K2 se mírně uklání k jihovýchodu. Póly k magnetické foliaci, které představují směr K3, ukazují, že magnetická foliace je mírně ukloněná převážně jjv. směrem. Celková susceptibilita měřených vzorků, kterou představuje parametr $\mathrm{K}_{\text {mean }}=\left(\mathrm{K}_{1}+\mathrm{K}_{2}+\mathrm{K}_{3}\right) / 3$ se pohybovala v rozmezí hodnot $43,71 \times 10^{-6} \mathrm{SI}($ nejnižší) a $53,74 \times$

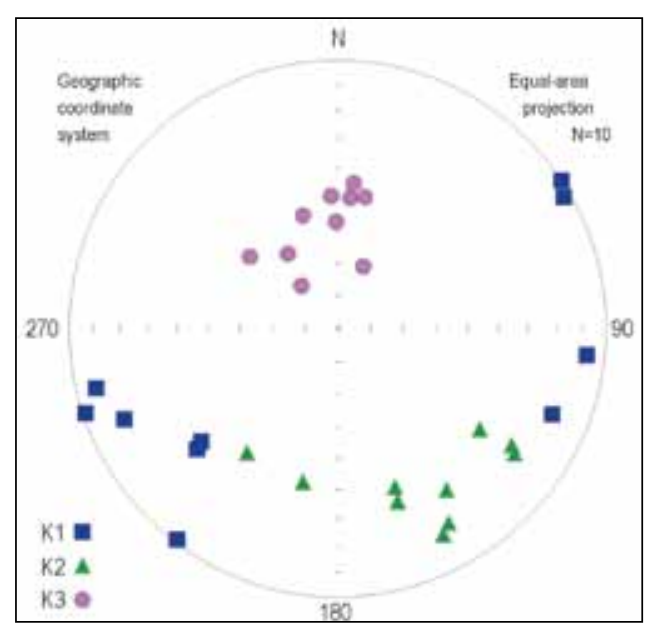

Obr. 4: Směry hlavních magnetických susceptibilit (v azimutální Lambertově projekci na spodní polokouli). Většími značkami jsou zobrazeny střední hodnoty. Vysvětlivky: K1 - magnetická lineace, K2 - střední hodnota, K3 - póly $\mathrm{k}$ magnetické foliaci.

Fig. 4: Directions of the main magnetic susceptibilities (azimuthal Lambert projections on the lower hemisphere). Larger brands show the mean values. Keys: K1 - magnetic lineation, $\mathrm{K} 2$ - intermediate principal axes, K3 - poles to magnetic foliation.
$10^{-6} \mathrm{SI}$ (nejvyšší). Tvarový parametr $\mathrm{T}=2 \ln \left(\mathrm{K}_{2} / \mathrm{K}_{3}\right) / \ln \left(\mathrm{K}_{1} /\right.$ $\mathrm{K}_{3}$ ) - 1 vyšel ve všech př́padech $\mathrm{v}$ rozmezí hodnot 0 až 1 , což představuje oblátní stavbu s dominancí magnetické foliace. Poměr parametrů $\mathrm{K}_{1}$ a $\mathrm{K}_{3}\left(\mathrm{P}=\mathrm{K}_{1} / \mathrm{K}_{3}\right)$, který představuje míru anizotropie, se pohyboval $v$ rozmezí hodnot 1,035 (nejnižší) až 1,053 (nejvyšší).

\section{Diskuze}

Orientace plochy zlomu naměřená kompasem a orientace vrstevnatosti v bodě B odpovídají očekávaným hodnotám, kde je směr okrajového zlomu SZ-JV $\mathrm{s}$ úklonem $\mathrm{k} J Z$. Toto zjištění je tak v souladu se staršími pozorováními (Melichar - Čech 1999).

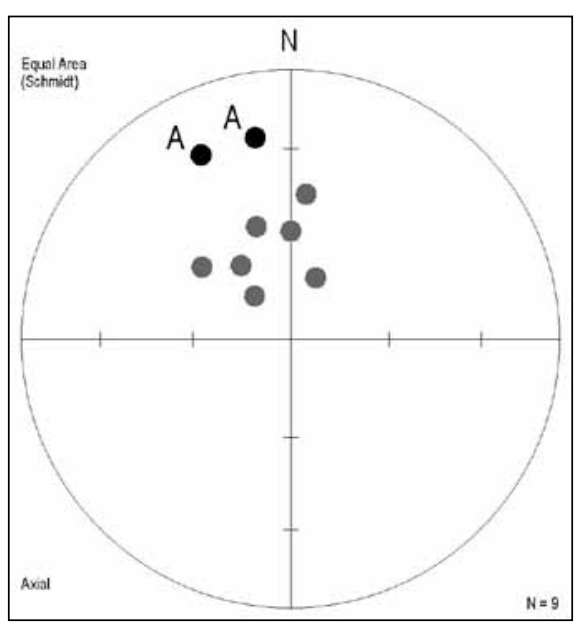

Obr. 5: Póly ploch vrstevnatosti (A) a magnetické foliace z jádra zlomu (v azimutální Lambertově projekci na spodní polokouli). Fig. 5: Poles of bedding surfaces (A) and magnetic foliations of fault core (azimuthal Lambert projections on the lower hemisphere).

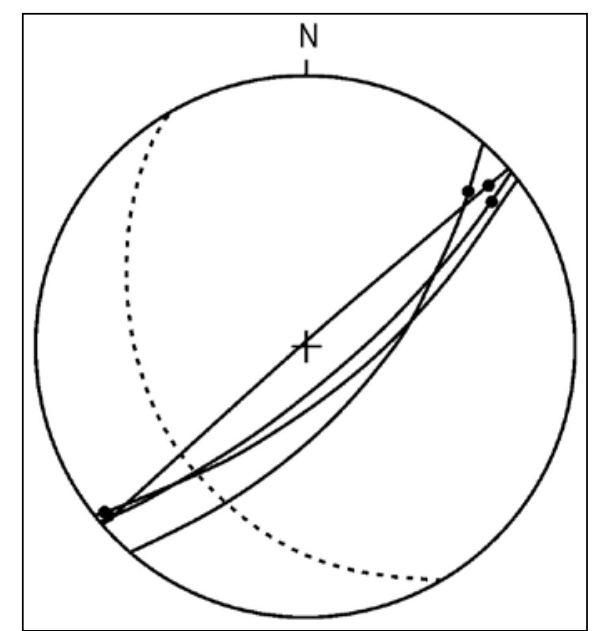

Obr. 6: Orientace ploch mikrozlomů (velké oblouky) a jejich rýhování (body) v žíle bazické horniny v těsné blízkosti okrajového zlomu (Havír 1998). Azimutální Lambertova projekce na spodní polokouli).

Fig. 6: Orientation of microfaults surfaces (great circles) and striae (points) from basic rock dike in close setting to marginal fault (Havír 1998), azimuthal Lambert projections on the lower hemisphere. 
Vrstevnatosti naměřené na lokalitě A a magnetické foliace $\mathrm{z}$ analýzy AMS z tektonicky postižených jílů však ukázaly neočekávané orientace, a to ve směru SV-JZ s proměnlivým sklonem $\mathrm{kJV}$ (obr. 5). Tyto výsledky jsou tedy oproti těm očekávaným otočené o 90 stupňů proti směru hodinových ručiček. Kontrolní vzorky odebrané v různých směrech ukázaly, že se nemůže jednat o chybu při určování orientace vzorků či o omyl při nastavení přístroje. Vzhledem k orientaci svahu se nemůže jednat ani o následek deformace svahovými pohyby (svah je ukloněný k SV). Jako jediné možné vysvětlení se tedy naskýtá tektonická deformace podél jiného zlomu než je zlom okrajový, tedy na nějakém příčném zlomu. Takový systém příčných zlomů ve směru SV-JZ (obr. 6) byl popsaný Havírem (1998), který našel zlomy s horizontálním rýhováním stejného směru jako má zjištěná magnetická lineace $\mathrm{v}$ deformovaném jílu. Lze tedy odůvodněně předpokládat, že zkoumaná lokalita zahrnuje jak deformace při okrajovém zlomu blanenského prolomu, tak i deformace spojené s doposud blíže neznámým př́ičným zlomem, který by mohl odpovídat systému popsanému Havířem (1998).

\section{Závěr}

Naměřená plocha zlomu a vrstevnatosti v křídových sedimentech v bodech $\mathrm{B}$ a C nám napovídají, že křídové sedimenty $\mathrm{v}$ blízkosti blanenského prolomu tvoří překocenou vrásu s velmi strmou vrstevnatostí, jejíž vznik je spojený s pohybem na okrajovém zlomu blanenského prolomu (Zvejška 1944; Melichar - Čech 1999).

Výsledky z AMS se jeví na Lambertově projekci na spodní polokouli pootočené vưči očekávané orientaci rýhování a zbylým naměřeným hodnotám, avšak jsou v souladu s vrstevnatostmi v bodě A, které jsou od ostatních taktéž odkloněné. Současně je magnetická lineace horizontální. To bylo zřejmě způsobeno deformacemi spojenými s horizontálními pohyby na nějakém drobném příčném zlomu směru SV-JZ, srovnatelným s mikrozlomy, které popsal Havíř (1998).

\section{Literatura}

Havír. J. (1998): Napětové a deformační pole ve vybraných regionech východní části českého masivu. - MS dizertační práce. Přírodovědecká fakulta Masarykova univerzita Brno. K 7253.

Kettner, R. (1941): Blanenský prolom. - Sborník České společnosti zeměpisné, 46, 113-118. Praha.

Melichar, R. - Čech, S. (1999): Blansko - Dolní Lhota. - Geolines, 8, 90.

Tarling, D. H. - Hrouda, F. (1993): The magnetic anisotropy of rocks - Chapman \& Hall London.

Zvejška, F. (1944): Blanenský prolom. - Práce Moravské př́rodovědecké společnosti, 16, 1, 1-29. 